D0l: $10.19195 / 2353-8546.4 .10$

KRIŠTOF JACEK KOZAK*

Univerza na Primorskem (Koper, Slovenija)

\title{
Rozkład świata na miarę człowieka: współczesność z perspektywy słoweńskiego dramatopisarstwa
}

\author{
„L'homme est né libre et partout il est dans les fers". \\ J.J. Rousseau, Du Contrat Social ou Principes du droit politique
}

The layout of the world tailored to the human. Contemporary world in Slovenian drama. This paper deals with the present-day Slovenian dramatic works facing the challenges of the contemporary world on the one hand and the consequent changes our society has been subject to on the other. Particular attention is paid to three main topics: discarded human beings (or G. Agamben's homines sacri), globalization or, in other words, "liquidity" of the modern world (cf. Z. Bauman's (in)famous definition), and the devolution of both Christian as well as Enlightenment values and norms. By way of an in-depth analysis, the paper will bring into picture sociological, anthropological, political, economic and other perspectives in the newest Slovenian drama. The paper's central argument will be the present-day emptiness of norms such as the Decalogue or Kant's categorical imperative. Such an up-to-date account of the dramatic endeavours in Slovenia necessarily paints a rather morbid picture of our contemporary world.

Keywords: Slovenian contemporary drama, globalization, traditional values, homo sacer, Christianity, neoliberalism

* Adres do korespondencji: Univerza na Primorskem Fakulteta za humanistične študije, Titov trg 5, 6000 Koper, Slovenija. E-mail: kristof.jacek.kozak@fhs.upr.si. 
Načrt sveta, narejenega po človekovi meri: sodobna slovenska drama tika. Pričujoči članek se ukvarja s sodobnimi slovenskimi dramskimi deli, ki se spopadajo $\mathrm{z}$ izzivi današnjega sveta $\mathrm{z}$ ene in posledičnimi spremembami naše družbe $z$ druge strani. Posebno pozornost posveča trem osrednjim temam: odpisanim človeškim bitjem (oziroma Agambenovim homines sacri), globalizaciji ali, z drugimi besedami, „tekočosti“ sodobnega sveta (prim. (ne)slavno definicijo Z. Baumana) in razkroju tako krščanskih kot razsvetljenskih vrednot in norm. S pomočjo poglobljene analize osvetli članek sociološke, antropološke, politične, ekonomske in druge perspektive v najnovejših slovenskih dramah. Osrednji argument v članku je sodobna izpraznjenost norm, kot je na primer deset božjih zapovedi ali Kantov kategorični imperativ. Takšno posodobljeno poročilo o slovenskih dramskih prizadevanjih nujno kažejo precej morbidno sliko našega današnjega sveta.

Ključne besede: slovenska sodobna dramatika, globalizacija, tradicionalne vrednote, homo sacer, krščanstvo, neoliberalizem

Już od zarania dziejów dramat uchodził za rodzaj literacki, który — jak to wyraził później Shakespeare - był dla świata zwierciadłem. Jednak w większości przypadków należałoby mówić o postawie pośredniej, autorów bowiem interesowało życie poszczególnych ludzi (Arystotelesa chociażby ciekawił li tylko charakter, a nie czyn — działanie - postaci dramatu, co z kolei przyciągało uwagę Hegla) i dopiero poprzez te poszczególne losy dawało się rekonstruować obrazy stosunków społecznych, w których dramatopisarze umieszczali swoich protagonistów. To przecież z osobistej tragedii Hamleta wysnuwamy wniosek o „zgniliźnie” państwa duńskiego. Tragedie antyczne (także znaczna część dzieł epoki elżbietańskiej i klasycystycznej) rzeczywiście ukazywały jednostki i ich losy, jednak protagonistów tych tworzono na miarę społeczeństwa, czy byli to władcy państw, czy przedstawiciele najszlachetniejszych rodów: Edyp to władca Teb; Agamemnon jest królem Argolidy; sprzeciwiająca się Kreonowi Antygona to córka Edypa; Medea, córka króla Kolchidy, wnuczka Heliosa, zabija Jazona, następcę tronu w Jolkos itd. Przynajmniej co do cyklu tebańskiego można stwierdzić, że wraz z upadkiem władcy lub jego rodu kończy się również konkretna forma społeczna, dlatego dla większości tych protagonistów można by użyć syntagmy Króla Słońce l'état c’est moi: ich los był tożsamy z losem ich państw.

Bez wątpienia porównanie tragedii antycznych ze współczesnymi dramatami prowadzi do oczywistego wniosku o ich nieprzystawalności. Zmienili się protagoniści: na scenie stają przedstawiciele wszystkich warstw społecznych nowszych czasów. I chociaż postaci są typowe i psychologicznie pogłębione, a ich poszczególne losy są teraz wyłącznie ich losami, można by wnioskować, że ci protagoniści nie odzwierciedlają już stanu społeczeństwa. Bez względu na to nie można jednak całkiem zignorować wyczuwalnych w tle stosunków społecznych, bo osoby dramatu zmuszone są odnosić się właśnie do nich. Współczesnymi protagonistami (po)zostają jednostki, ale z przebiegu ich dramatycznych losów zawsze można wnioskować o aktualnym stanie społeczeństwa i świata: na podstawie losu Willy’ego Lomana A. Millera poznajemy społeczność amerykańską zaraz po II wojnie światowej, a z dramatu M. Ravne- 
hilla Shopping and Fucking Wielką Brytanię z końca XX wieku. Nawet jeżeli zupełne uogólnienie nie jest możliwe, to mimo wszystko można powiedzieć, że bez względu na wcześniejsze ustalenia, różnica między dawniejszą a współczesną dramaturgią w obrazowaniu wymiarów życia społecznego jest mniejsza, niżby się to na pierwszy rzut oka mogło wydawać. Jeśli antyczni protagoniści byli niemal uosobieniem państwa, to dzisiejsi są ledwie pars pro toto, a mimo to oba wymienione współczesne teksty mają podobny, jeżeli nawet nie większy, potencjał informacyjny niż utwory z przeszłości. Także na podstawie współczesnych tekstów dramatycznych wnioskować można o dzisiejszej kondycji świata, a dokładniej — o współczesnym rozkładzie całego systemu. Słoweńskie sztuki teatralne pod tym względem nie pozostają w tyle za tekstami światowymi, wyrażając może nawet większe zaangażowanie.

Po II wojnie światowej słoweńska literatura dramatyczna rozwijała się w specyficzny sposób, zmagając się — mniej lub bardziej bezpośrednio - z systemem społecznym przede wszystkim poprzez dramat poetycki i dramat absurdu, podczas gdy otwarty, ostry, dramat polityczny był w niej mniej obecny. Zatem o klimacie społecznym, w którym powstawała taka literatura dramatyczna, można było wnioskować głównie na podstawie tekstów bądź to jawnie absurdalnych (P. Božič, D. Jovanović, M. Jesih, E. Flisar, M. Zupančič), bądź poetyckich (D. Smole, D. Zajc, G. Strniša, V. Taufer, I. Svetina, R. Šeligo, B.A. Novak).

Oba opisane kierunki obecne są i dzisiaj w słoweńskim dramacie, jednak obecnie dramat ten jest znaczniej bardziej zaangażowany. Bez żadnych zahamowań przedstawia zepsucie współczesnego świata, cierpienie, które sprowadza on na jednostki, a poprzez nie na całe grupy społeczne. Słoweński filozof M. Dolar zapisał kiedyś, że dzisiaj słynną 11. tezę Marksa o Feuerbachu należy rozumieć odwrotnie: nie chodzi mianowicie o to, by zmieniać świat, lecz przede wszystkim, by go rozumieć. Właśnie w tym ujęciu słoweńska literatura dramatyczna staje się bardzo nowoczesna, zadziwiająco współbrzmi ze współczesną myślą filozoficzną i socjologiczną, które pomogą nam w analizie słoweńskich tekstów dramatycznych.

Jak wspomnieliśmy, współczesny świat charakteryzują w Słowenii dramaty poświęcone jednostkom i ich - mniej lub bardziej tragicznym - losom. Nawet jeśli nie zawierają bezpośredniej krytyki i nie wskazują winnych zaistniałej sytuacji, to ukazują one cierpienie człowieka w krzywdzącym go świecie. Dramatopisarze w swych tekstach opisują losy pojedynczych ludzi, konkretnie komentują realne sytuacje wbrew postmodernistycznej świadomości o upadku grands récits. Wśród dramaturgów tej grupy wyróżnia się Draga Potočnjak. Jest jednym z nielicznych autorów zajmujących się dwoma jak najbardziej współczesnymi tematami: wojną w byłej Jugosławii i wyrzutkami społeczeństwa, ludźmi marginesu. Dodajmy, że kreatywnie na wojnę bałkańską zareagowali także Dušan Jovanović 
swą Trylogia Bałkańską (w całości wydaną w 1997 r.), na którą składają się Zagadka Courrage (1994), Antygona (1996) i Któż to śpiewa Syzyfa (1997), jak też Boris A. Novak w tragedii Kassandra (2001). Mimo że głos Potočnjak był niemal głosem wołającego na pustyni, to jednak wybrzmiał jasno i głośno, osądzając krzywdy, jakich doznają stygmatyzowani ludzie $\mathrm{z}$ dna społecznego. W swoich sztukach autorka zajęła się uciekinierami wojennymi (Alisa, Alisa, 1996), Romami (Kalea, 2000), chorymi psychicznie (Zwierzęcy harmider jest nieznośny, 2003), ludźmi nieszczęśliwymi i wykluczonymi (Taniec motyli, 2003), kobietami ofiarami przemocy ( $W$ imieniu naszych młodych dam, 2006). Ostatnia sztuka otrzymała nagrodę Gruma za najlepszy słoweński tekst teatralny za rok 2006. Jednym słowem Potočnjak pochyla się nad tymi, którym daleko do surrealistycznych, plastikowych postaci z ekranów telewizyjnych.

Kryzysem jednostki, a dokładniej, relacjami międzyludzkimi zajmuje się w swoich - uhonorowanych nagrodą Gruma - tekstach: 5chłopców.si (2008, nagroda 2009) oraz Doba (2009, nagroda 2010) młoda dramatopisarka Simona Semenič. Pierwszy z nich poprzez zabawy pięciu chłopców opisuje wynaturzenia świata dorosłych, na które wszyscy dziś dajemy przyzwolenie, drugi natomiast negliżuje jałowe relacje międzyludzkie. W obu sztukach bohaterowie nie tylko tracą kontakt $\mathrm{z}$ innymi ludźmi, lecz także zostają ogołoceni przede wszystkim z samych siebie, z podstawowych wartości ludzkich. Dla dzisiejszego kapitalizmu mają wartość jedynie jako konsumenci lub jako ludzie przez społeczeństwo odrzuceni, służący konsolidacji społeczeństwa per negationem. Są bowiem figurą wroga, wobec którego inni mogą poczuć się wspólnotą.

Ten typ egzystencji ludzkiej w 1995 roku wstrząsająco zdefiniował włoski filozof Giorgio Agamben i nazwał, opierając się na prawie rzymskim, homo sacer. Syntagma ta nie oznacza „świętości”, lecz zwraca uwagę na uprzedmiotowienie określonej grupy ludzi. Według Agambena homo sacer jest produktem nowoczesności, która człowieka zdewaluowała, odebrała mu jego społeczną naturę, a jedyne, co mu pozostawiła, to „ogołocone życie”, kategorię, która „istnieje w ciele biologicznym

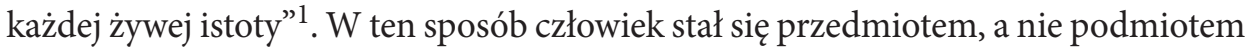
polityki jako funkcji polis. Święty człowiek jest równocześnie „święty i przeklęty”2, nie może się bowiem odnaleźć ani w świecie sacrum, ani profanum, nie podlega zwykłym prawom, które regulują relacje międzyludzkie. Dlatego, jak powiada Agamben, takiego człowieka wolno nawet zabić. Zawieszony jest pomiędzy dwoma światami, egzystuje „poza”. Jego życie zyskuje nowy sens w społeczeństwie, ponieważ przerwanie jego życia - przy jednoczesnej niemożności złożenia z niego ofiary - staje się fundamentem konfiguracji politycznej (taki typ ogołoconego życia Agamben odnajduje w obozach koncentracyjnych) $)^{3}$. Takie pozbawione praw, ogołocone egzystencje możemy odnaleźć i w naszych społecznościach. Mają one inną rolę do spełnienia, ich śmierć w gruncie rzeczy konsoliduje społeczeństwo, zwierając jego szeregi. Problem,

\footnotetext{
${ }^{1}$ G. Agamben, Homo sacer: suverena oblast in golo življenje, Ljubljana 2004, s. 151.

2 Ibidem, s. 88.

${ }^{3}$ Ibidem, s. 99.
} 
który Agamben widzi we współczesnym świecie, polega na tym, że świat ten zniszczył tradycyjne podziały w obrębie zwykłych międzyludzkich, społecznych, a także etnicznych kategorii. Wśród ludzi, zaliczanych do tej grupy przez Agambena, są np. dzisiejsi uchodźcy, którzy

przerywając ciągłość pomiędzy człowiekiem a obywatelem, między narodzinami a narodowościa, ujawniają kryzys źródłowej fikcji nowoczesnej suwerenności. W momencie obnażenia tego, co pozostało z więzi pomiędzy narodzinami a narodem, uchodźca przez moment na scenie politycznej staje się ucieleśnieniem życia ogołoconego, ukrytego potencjalnie w każdym z nas ${ }^{4}$.

W tej roli występują przede wszystkim społeczni pariasi, wywodzący się dziś z zaniedbanych warstw społecznych: nielegalnych imigrantów, oczekujących na azyl uchodźców, Romów, psychicznie chorych itd.

Jeżeli teksty dramatyczne odczytamy w ten sposób, ukażą nam one również swoją społeczną perspektywę, ponieważ poprzez indywidualne losy precyzyjnie zarysowują obraz społeczeństwa w całej jego złożoności. Ponownie należy tu wymienić sztukę Dragi Potočnjak Alisa, Alisa, jak też najnowsze teksty Matjaža Zupančiča Shocking Shopping (2010, nagroda Gruma 2011) i Upadek Europy (2011) oraz Ćwiczenia $z$ depresji (2011, nagroda Gruma 2012) Vinka Möderndorfera.

W sztuce Alisa, Alisa D. Potočnjak przedstawia wprawdzie indywidualny konflikt uciekinierki bośniackiej Alisy, lecz sytuuje ją zarazem w kategorii „ludzi świętych" i właśnie to sprawia, że można ją uważać za ofiarę przemocy. Jest to przede wszystkim bezsilny protest autorki przeciwko wojnie w byłej Jugosławii, a także oskarżenie społeczności, która pod maską filantropii pozwala na przemoc psychiczną wobec tych ludzi, wreszcie krytyka społecznej psychopatologii, w której obrębie znęcanie się nad innymi staje się źródłem lepszego samopoczucia. Młoda dziewczyna zbieżność z imieniem Alicji z Krainy Czarów nie jest przypadkowa — staje się ofiarą tych społecznych zachowań, które uosabia słoweńska drobnomieszczanka, obnażając zarazem zakłamanie i zepsucie społeczeństwa dającego na to przyzwolenie. Ponieważ Alisa nie potrafi sprzeciwić się swojej „wybawicielce”, wybiera samobójstwo. Tak więc owa uciekinierka na ołtarzu „normalności” dzisiejszego wykolejonego świata składa samą siebie w ofierze. Oskarżenie okrutnego, niemoralnego społeczeństwa brzmi tu wyjątkowo ostro i szczerze.

Podobną, lecz nie tak otwartą krytykę zawiera tekst Matjaža Zupančiča Shocking Shopping. Tematem głównym jest tu władza kapitału oraz nadużyć, jakich się wobec ludzi dopuszcza. Kapitał panuje dziś nad ludźmi nie tylko ze szczytu społecznych struktur, ale też w dystansie przestrzennym, „na odległość”, co według polskiego socjologa Zygmunta Baumana jest istotnym novum płynnej nowoczesności. Wraz z rozkładem „podstawowej komórki społecznej”, jak określił rodzinę Karol Marks, człowiek w zglobalizowanym świecie stał się samotny i zagubiony, a kapitalizm w za-

${ }^{4}$ Ibidem, s. 142. 
mian za poczucie bezpieczeństwa oferuje mu konsumpcjonizm jako najwyższe dobro: swoje szczęście człowiek może znaleźć jeszcze tylko w galeriach handlowych.

Niemal do absurdu Zupančič doprowadza sytuację, która mogłaby się zdarzyć każdemu z nas. Homo sacer to u Zupančiča szary człowiek, który w galerii handlowej wygrywa nagrodę. Gdy ją odbiera i podpisuje na zapleczu stosy dokumentów, sprawy zaczynają się komplikować, bohater staje się świadkiem morderstwa, choć go na własne oczy nie widzi. Słyszy tylko, jak blisko niego niezrównoważony ochroniarz, przestępca z marginesu społecznego, zabija przyłapanego na kradzieży złodziejaszka. Chcąc zatuszować to zdarzenie, kierownik galerii przekonuje zdobywcę nagrody, aby o wszystkim zapomniał, a ten dając się złapać w pułapkę własnej logiki, staje się ofiarą logicznej natury języka. Nie może zapomnieć o zdarzeniu, chociaż niczego nie widział. Precyzja w wysławianiu się i drobny techniczny szczegół sprawią, że przypłaci to życiem. Rozjuszony ochroniarz skręca mu kark. Człowiek w sztuce Zupančiča przestaje być człowiekiem, podmiotem, staje się pustą jednostką, która ma tylko jedno zadanie - ma być „karmą” dla nienasyconej konsumpcyjnej machiny. Wychodząc z tej roli, skazuje się na unicestwienie.

Ostatni tekst Zupančiča Upadek Europy opisuje otwarcie pensjonatu Europa $\mathrm{z}$ udziałem miejscowej drobnomieszczańskiej elity, podczas gdy na ulicach w tym samym czasie wybuchają protesty przeciwko degradacji społecznej mieszkańców miasta. Sztuka obnaża demoralizację większości protagonistów, którzy urządzają sobie zabawę z udziałem Nieznajomego, złapanego przez hotelowego ochroniarza uczestnika protestów. Miejscy notable, bawiąc się jego kosztem, wymyślają coraz to dziwniejsze harce, a gdy Nieznajomy próbuje ratować się ucieczką, zostaje przez ochroniarza zabity. Nie zasługuje nawet na miano ustrzelonej zwierzyny łownej, jego „odczłowieczenie” jest tu totalne. Zupančič nie nadaje mu imienia, nie udziela głosu, jego postać jest dla uczestników bankietu tylko dlatego interesująca, że się porusza i od czasu do czasu próbuje się bronić. Niewątpliwie Nieznanego można by zaliczyć do najbardziej agambenowskich figur we współczesnym dramatopisarstwie słoweńskim.

Ćwiczenia z depresji Möderndorfera to dzieło, którego podtytuł Sztuka o dniu dzisiejszym daje do zrozumienia, iż chodzi tu o kompleksowy obraz relacji międzyludzkich. W Ćwiczeniach świat podzielony jest zgodnie ze współczesnymi zapowiedziami, chociażby Paula Krugmana ${ }^{5}$. Świat z grubsza dzieli się na dwie warstwy społeczne, ponieważ trzecia, średnia klasa, „klasa inteligencji”, zdaniem Krugmana stacza się po równi pochyłej w coraz większą biedę, ulegając pauperyzacji, i właściwie zanika (pisał o tym również Noam Chomsky w książce Zysk przed ludźmi) ${ }^{6}$. Na pewno nieprzypadkowo Möderndorfer wybrał sobie cytat z tej książki jako motto innego swojego dramatu zatytułowanego Dziesięć.

\footnotetext{
${ }^{5}$ P. Krugman, Class Wars of 2012, „New York Times”, 29 listopada 2012.

${ }^{6}$ N. Chomsky, Profit pred ljudmi: neoliberalizem in globalna ureditev, Ljubljana 2005.
} 
Najliczniejsza jest (naj)niższa warstwa (na marginesie światowych protestów ostatnich lat możemy zapisać, że chodzi o większość słynnych 99\%), która niebezpiecznie zbliża się do progu nędzy. Są to ludzie, którym z tych czy innych powodów (niepełne wykształcenie, bierność, strach, brak zaangażowania itp.) nie udało się przebić do sfery bogat(sz)ych. Tak więc symbolicznie ukazane jest społeczeństwo $\mathrm{w}$ aspekcie klasowych przeciwieństw i najniższych warstw społecznych: zbytecznych robotników, bezrobotnych sprzątaczek, egzystencjalnie zależnych od właściciela/zleceniodawcy pracowników, którzy jak zombi spełniają polecenia „pana”, stając się tylko „trybikiem” w systemie.

Ofiary dzisiejszego systemu to w tej sztuce: Starszy robotnik i jego Córka, Młodszy robotnik, Sprzątaczka Štefika i jej Bezrobotny mąż Emir, a łączy ich typowa dla dzisiejszego proletariatu cecha - zbyteczność, ponieważ w celu zmaksymalizowania zysków kapitał wykorzystuje bardziej „konkurencyjną” siłę roboczą z innych, odleglejszych regionów (tzw. outsourcing). Położenie bohaterów jest jasne: są bezrobotni, nie mają prawa głosu, nie znajdują wyjścia z sytuacji, w której się znaleźli, więc kolejno targają się na swoje życie (samookaleczenie, samobójstwo), po prostu wpędzeni w ślepy zaułek wyrzekają się również najzwyklejszej ludzkiej solidarności. Każdy egzystuje oddzielnie, stając się łatwym łupem kapitału. W tym sensie najbardziej wstrząsający jest los Šefiki, matki dwojga dzieci, sprzątaczki, która $\mathrm{z}$ dnia na dzień staje się w przedsiębiorstwie „nadwyżką technologiczną”. Po utracie pracy nie może nakarmić dzieci, więc „ucieka [...] przed ich płaczem. Zamyka się [...] w toalecie, póki nie zasną" żeli nie można ich nakarmić”. Później dowiadujemy się, że najpierw morduje dzieci, a potem zabija siebie. Uprzedzając potencjalne zarzuty, że są to ekstremalne obrazy pojedynczych losów, należy podkreślić, że jeszcze przed Agambenem uznani socjologowie przepowiadali identyczne losy. Jednym z nich był René Girard, który swoją teorią przemocy, rozumianą jako siła dośrodkowa wspólnoty, uzasadnił rytualną ofiarę wybranych spośród niej jednostek. Chodzi więc o grupę ludzi, których w celu konsolidacji wspólnoty można, o ile nawet nie trzeba, złożyć w ofierze. Są to „jednostki z zewnątrz lub z marginesu, które nie potrafią stworzyć lub pielęgnować więzi społecznych. Status ludzi obcych, wrogów, status niewolnika, lub nawet starość uniemożliwiają owym przyszłym ofiarom integrację ze wspólnotą" ${ }^{8}$. Tak więc ludzie, którzy wypadają z systemu kół zębatych, z dnia na dzień stają się zbyteczni. Bauman ujął to następująco:

Liposukcja jako ekwiwalent sztuki zarządzania stała się jej podstawowym chwytem: główne narzędzia tej nowej sztuki to odchudzanie, ograniczanie, stopniowe zamykanie lub wyprzedawanie zakładów z powodu zbyt małej ich wydajności lub przekonania, że taniej jest pozwolić im, by same zawalczyły o przeżycie ${ }^{9}$.

\footnotetext{
7 V. Möderndorfer, Vaje iz tesnobe,„Sodobnost” 2012, vol. 76, No 7/8, s. 20.

${ }^{8}$ Cyt. za: Z. Baumann, Tekoča moderna, Ljubljana 2002, s. 245.

${ }^{9}$ Ibidem, s. 156.
} 
Kapitalista nie działa rzecz jasna sam, lecz otoczony jest rojem zależnych od niego ludzi, którzy albo starają się zająć jego miejsce, albo muszą się mu podporządkować. W sztuce Möderndorfera „odczłowieczona” jest także forma. Dialog budują pojedyncze wersy, które ukazują ludzi niezdolnych do jakiejkolwiek głębszej myśli. Ludziom tym raczej nie przyszłyby do głowy takie obrazoburcze w dzisiejszym świecie wartości, jak równość, sprawiedliwość, solidarność. Bierne istnienie w danej sytuacji, oczekiwanie na następny „cios losu”, sprowadzanie człowieka wyłącznie do nagiej egzystencji, wszystko to oznacza coraz większe odczłowieczenie. Ćwiczenia $z$ depresji to mroczny portret współczesnego zachodniego świata, który coraz bardziej otumaniony powtarza friedmanowską mantrę neoliberalizmu, w obrębie którego nie da się uciec przed wyzyskiem, a my wszyscy stopniowo stajemy się homines sacri. Wymienione sztuki przedstawiają pojedyncze losy ludzi żyjących „życiem niewartym życia” ${ }^{10}$. Szokujące właściwie jest nie to, że takie byty $\mathrm{w}$ ogóle istnieją, $\mathrm{z}$ historii znamy przecież rozmaite formy porządków społecznych, lecz to, że takie losy zdarzają się dzisiaj, gdy świat — parafrazując filozofa Panglosa z Kandyda Voltaire’a - który miał być „najlepszym z możliwych”, jeszcze ciągle nie tylko na to pozwala, ale wciąż na nowo „produkuje” takich ludzi...

\section{II}

„Płynna nowoczesność" to metafora, którą Zygmunt Bauman posługuje się, by zdefiniować świat współczesny. „Płynność” w obrazowym skrócie symbolizuje tu istotne cechy epoki: niestałość, niepewność, nieokreśloność, i co za tym idzie - strach. Przede wszystkim strach o własną egzystencję. Książka Baumana o tym samym tytule ukazała się w roku 2000 jako złowieszcza zapowiedź czasów, które nie nadchodzą, lecz już tu są, autor bowiem nie ma już żadnych złudzeń: stary świat, świat „tradycyjnej lojalności, zwykłych praw i powinności”ll już ostatecznie przeminął, powrotu do dawnego sposobu bycia nie będzie i jedyne, co nam pozostaje, to jak najlepsze dostosowanie się do nowej sytuacji. Stan współczesny bezwzględnie wyznacza i określa ekonomia neoliberalna, która poprzez globalizację ostatecznie zawłaszczyła także światową politykę, a swoje prawa - możemy je nazwać „darwinizmem społecznym” - rozszerzyła na wszystkie segmenty współczesnego społeczeństwa. Upraszczając, kapitalizm neoliberalny nie dba o człowieka, a to zagraża podstawowym wartościom wspólnoty. Dla nowoczesnego kapitalizmu wyizolowana jednostka jest znacznie łatwiejszą „zdobyczą” niż dobrze zorganizowana grupa, dlatego współczesny świat pragnie człowieka odizolować, zatomizować, kolektywne wartości, jak

\footnotetext{
${ }^{10}$ G. Agamben, op. cit., s.147.

11 Z. Bauman, op. cit., s. 8.
} 
choćby wolność, bezpieczeństwo i zaufanie stają się dziś względne, a tym samym bez znaczenia.

Opisane wartości utraciły swój absolutny, trwały autorytet i dostosowały się do zmian i giętkości nowych sytuacji egzystencjalnych. Więzi międzyludzkie zamiast stabilności i stałości zaakceptowały „rozkład, atomizację, kruchość, przejściowość, tymczasowość" ${ }^{12}$. Ponieważ niestałe więzi wymagają od człowieka, by nieustannie się zmieniał, niebezpieczeństwo zagraża również istocie człowieka: zamiast podmiotu, jak by to nazwał A. Badiou, pojawia się indywiduum, czyli zamiast tożsamości tylko (chwilowa) identyfikacja. W ten sposób dzisiejsze „wspólnoty [...] są odtąd jedynie efemerycznymi artefaktami tymczasowej gry indywidualności, a nie siłami określającymi i definiującymi tożsamości"13. Fundament, podstawa bezpieczeństwa jednostki, nie istnieje. Kryzys, który ogarnął też podstawowe ludzkie potrzeby, ma charakter nie tylko etyczny, lecz także ontologiczny, ponieważ dotyka każdego człowieka jako jednostki, a nie przedstawiciela klasy lub jakiejś grupy interesów.

W „starym świecie” człowiek mógł się realizować w ramach swojej warstwy społecznej i za jej pośrednictwem budował społeczne więzi, dzisiaj nieprzynależność oznacza pełną „swobodę” i (pozorną) odpowiedzialność za siebie samego. Jak na razie, rozwiązania nie widać, albowiem żadna rewolucja czy jakakolwiek inna forma oporu (bez względu na to, co mówi Stéphane Hessel w swojej książce Indignez-vous) nie jest możliwa, ponieważ — jak pisze Bauman — „dzisiaj nie sumuje się najczęstszych problemów jednostek"14. Społeczeństwo odrzuciło odpowiedzialność za pojedynczego człowieka, umyło ręce, obwiniając go za jego niepowodzenia. Mamy wprawdzie receptę na rozwiązanie problemu: amerykański sen, który każdemu z nas obiecuje sukces, jeśli tylko jesteśmy wystarczająco zdeterminowani i odpowiednio się staramy. Jednakże dla większości z nas urzeczywistnienie tego snu jest tak samo realne, jak przejście wielbłąda przez ucho igielne.

Pragnienie sukcesu sprawia, że współczesny neoliberalizm, posługując się instrumentami i mechanizmami kapitału, panuje nad dzisiejszym człowiekiem. Współczesne społeczeństwo „dyskurs etyczny/polityczny przeniosło z ram »społeczeństwa sprawiedliwego« na płaszczyznę "praw człowieka«"15. Jednostka jest przekonana, że ma tylko prawa, które należą się jej w sposób naturalny, ale nie pyta, czy na nie w ogóle zasługuje. Współczesne społeczeństwo opiera się na „wymykającej się i ciągle nieuchwytnej obietnicy beztroskiego życia" ${ }^{16}$. Przekonani, że prawa te automatycznie nam się należą, stajemy się zależni od nich i w rezultacie gotowi je-

\footnotetext{
12 Ibidem, s. 21.

${ }^{13}$ Ibidem, s. 31.

${ }^{14}$ Ibidem, s. 46.

15 Ibidem, s. 39.

16 Ibidem, s. 93.
} 
steśmy uczynić wszystko - wyrzec się nawet praw wcześniej wywalczonych - aby te „należne nam” prawa utrzymać. W taki sposób stajemy się wyłącznie „częściami zamiennymi” współczesnej maszynerii kapitałowej.

Niewątpliwie wśród słoweńskich dramatopisarzy Matjaž Zupančič uchodzi za jednego z najbardziej bezlitosnych krytyków współczesnego świata, zwłaszcza w ostatnich sztukach, które powstają już od roku 2000 (przede wszystkim Korytarz, 2002, nagroda Gruma 2003). W dwóch pierwszych dramatach z tego czasu Zupančič ograniczał się do opisu konkretnych zjawisk kulturowych: Korytarz opowiada o kręceniu programu reality show, a Klasa o szkoleniu marzącego o awansie pracownika wielkiej korporacji. W obu tekstach autor rozmyśla o ludzkich ułomnościach: w reality show ograniczenie przestrzeni, w której poruszają się i współzawodniczą uczestnicy programu, potęguje napięcie i wyzwala niegodne człowieka instynkty umożliwiające przeżycie najbardziej twardemu, chytremu i bezwzględnemu zawodnikowi. Natomiast pracownikowi z Klasy system szkolenia „łamie” kręgosłup, dla awansu gotów jest on zrobić i zgodzić się na wszystko za cenę własnego odczłowieczenia. W obu przypadkach mamy do czynienia z tą samą zasadą współczesnego życia, która doprowadza do rozkładu nie tylko ludzkich wartości, ale przede wszystkim istoty człowieczeństwa.

Podobnie bezlitosny dla współczesnych przedstawicieli kapitału okazuje się Drago Jančar w sztuce Lekka jazda (powstała w roku 2003, prapremiera w Słowenii w 2008). Spośród wszystkich jego sztuk Lekka jazda jest jedyną, której akcja toczy się w Słowenii i negliżuje ówczesną sytuację słoweńskiego społeczeństwa. Reprezentują je związani z władzą dyrektorzy fabryk, którzy na oczach całego kraju dotychczasową własność społeczną legalnie prywatyzują, chodzi zatem o proces, który już marksistowska ekonomia polityczna nazwała „pierwotną akumulacją kapitału". Jak dzisiaj wiemy, w żadnym państwie postsocjalistycznym prywatyzacja nie przebiegała właściwie, a już na pewno trudno ją nazwać sprawiedliwą. Jednocześnie jako społeczeństwo zaczęliśmmy popadać w konflikt ze zjawiskiem globalizacji, a więc wdzieraniem się gigantycznych przedsiębiorstw na znacznie lepiej dawniej zabezpieczony rynek lokalny. Jančar pokazuje zatem świat, który $\mathrm{z}$ jednej strony tkwi jeszcze w ramach tradycyjnych lokalnych wartości, a z drugiej - tęsknym okiem spogląda na świat otwarty i jego kapitalistyczne „dobra”. Bauman w swej książce o globalizacji ostrzega, że „immanentną częścią procesu globalizacji [...] jest coraz większa segregacja przestrzenna, separacja i wykluczanie" ${ }^{\prime 7}$, co z kolei wywołuje proces „erozji w lokalnych wspólnotach społecznych i kulturowych i sieje zwątpienie w ich sens" 18 . Właśnie ów proces rozkładu tradycyjnych wartości jest tematem tekstu Jančara, który na przeciwnym biegunie neoliberalnego społeczeństwa tworzy idyllę słoweńskiej prowincji. Kontrast między nimi jest tym większy, im bardziej przedstawiona przez niego lokalna Arkadia

17 Z. Bauman, Globalization: the human consequences, Cambridge 1998, s. 7.

${ }^{18}$ Ibidem, s. 20. 
nawiązuje do ikonografii słoweńskich sielankowych pagórków z wzniesionymi na ich szczytach barokowymi kościółkami. Są one metaforą bezpiecznego domowego zacisza, w którym życie toczyło się w ustalonym, od wieków prawie niezmienionym rytmie. Kontrast obu ukazanych światów i wartości, które ucieleśniają, jest osią głównego konfliktu dramatycznego: nowoczesny kapitalista i oligarcha, Maks Globokar, po nagłym objawieniu w wiejskim kościółku, pragnie wyrzec się poprzedniego pazernego życia. Jednak nadal określa go dwojaka właściwość przede wszystkim ta zglobalizowana, tkwi w nim przecież jego dawne ego, czyli człowiek sukcesu, najbogatszy biznesmen, najpotężniejszy oligarcha prywatyzacji, od którego wszystko zależy i który w gruncie rzeczy burzy tradycyjny porządek świata. Najlepiej charakteryzują go słowa Baumana: „Doświadczenie nowej elity to właśnie ta "pozaziemskość« władzy: nieprawdopodobna, przerażająca kombinacja eteryczności i absolutnej mocy, braku fizyczności i mocy kształtowania rzeczywistości”" ${ }^{\prime 19}$. A z drugiej strony właściwość ta ma też lokalny wymiar. Istotną cechą Maksa po nawróceniu jest swojskość, z jej (psychologicznym) poczuciem bezpieczeństwa zapisanym w stuletnich rytuałach i wartościach. Powodem konwersji jest zmęczenie pogonią za pieniędzmi, przesyt, nuda, wewnętrzna pustka, przerażenie ludzką (własną) nędzą, małością i nieistotnością. Wszystkiego ma już dość i chciałby rozpocząć nowe, bezgrzeszne życie. Zbyt wiele osób zależało jednak dawniej od niego, aby to mogło się udać. Do starego życia ciągnie go nie tylko rodzina i przyjaciele, domagający się jego opieki, ale też ci, z którymi wiążą go prywatyzacyjne interesy. Maks się nie poddaje, ale choć już nie jest jednym z nich, to wciąż trzyma ich w szachu, za dużo bowiem wie o ich sprawkach. Znowu chodzi tu o paradygmatyczną sytuację współczesnego społeczeństwa, co potwierdza Bauman, cytując Michela Croziera, który uważa, iż „manipulowanie niepewnością to istota dążenia do władzy”, ponieważ „największą władzę [...] posiadają te jednostki, które potrafią stać się źródłem niepewności dla innych"20. A ponieważ dawni kumple Maksa nie chcą się pogodzić z jego przewagą, muszą go zabić. Zostaje zastrzelony w kościele, gdy kontempluje świeżo odrestaurowany fresk.

Jančar rozwiązuje konflikt w sposób moralistyczny — na końcu jednak grzesznik zostaje napiętnowany. Podobnie jak poźniej Zupančič w Reklamach, seksie i obżarstwie, Jančar w roku 2003 jeszcze wierzy, że możliwe jest sprawiedliwe wyjście z zaistniałej sytuacji, a co po roku 2008, w coraz bardziej pogłębiającym się kryzysie świata zachodniego, okazuje się zdecydowanie mniej realne. W dzisiejszym świecie, którym rządzi darwinizm społeczny, problematyczne jest przede wszystkim założenie istnienia $z$ dawien dawna zapomnianych solidnych etycznych wartości: zgodnie z friedmanowską logiką dzisiejsze „modły” do złotego cielca nie zapowiadają niczego dobrego.

${ }^{19}$ Ibidem, s. 26.

${ }^{20}$ Cyt. za: ibidem, s. 42. 
III

Rozmiary upadku współczesnego społeczeństwa w Słowenii, choć niczym specjalnie nie różni się ono od innych społeczności w zachodnim świecie, niektórzy dramatopisarze zdecydowali się ukazać bezpośrednio, bez kamuflażu. Głębię kryzysu systemu opisują również teksty mówiące o absolutnym rozkładzie podstawowych wartości zachodniej cywilizacji. Autorzy bez ogródek mówią o kresie podstawowego systemu wartości zachodniej cywilizacji - chrześcijaństwa. Wartości były zawsze wyznacznikiem „reguł gry” we wspólnotach, ich spoiwem. O tym, że wspólnoty musiały działać w zgodzie z regułami, wiedziano od dawna: oprócz babilońskiego Kodeksu Hammurabiego (ok. XVIII wieku p.n.e.) judejski kodeks etyczny (5 Mz, 2-17, również $2 \mathrm{Mz} 20,1-17)$ - w odróżnieniu od rytualnego (2 Mz 34, 11-26) - był jednym z pierwszych tekstów zawierających wykaz reguł społecznych.

Mowa tu o Dziesięciu Przykazaniach, które wyznaczając reguły i zabraniając, paradoksalnie otwierały i wyzwalały, stawiając warunki i ograniczenia, tworzyły podstawy harmonijnego i swobodnego współżycia ludzkich społeczności. Wartości, na których opiera się Dekalog, są absolutne (żydzi i chrześcijanie są zgodni co do tego, że Mojżeszowi na górze Synaj sam Bóg ukazał się w gorejącym krzewie i podyktował Dziesięć Przykazań), a to oznacza, że obowiązują wszystkich i za ich złamanie trzeba nieuchronnie ponieść konsekwencje, dużo poważniejsze w przypadku wspólnoty niż jednostki. Wystąpienie przeciwko któremukolwiek przykazaniu narusza bowiem fundament harmonijnie żyjącej wspólnoty.

Konfrontacja dzisiejszego świata $\mathrm{z}$ idealistycznymi wartościami chrześcijańskimi ukazuje w pełni rozkład „umowy społecznej”, wyostrza bowiem rozumienie kryzysu, przeciwstawiając sobie nowoczesny i tradycyjny system wartości. Taka optyka, uwzględniająca inną, istniejącą już dwa tysiąclecia normę etyczną, wzmacnia też efekt oskarżenia obecnego stanu społeczeństwa. Bez względu na to, w jakim stopniu wartości chrześcijańskie są faktycznie respektowane i obecne w życiu ludzi, trzeba przyznać, że jest to jedyny system, który proponuje względnie skuteczny, a przynajmniej pełen nadziei system porządkowania stosunków społecznych. Wiemy jednak, że również ten system wraz $\mathrm{z}$ atomizacją i komercjalizacją społeczeństw ulega rozpadowi. Czcimy dzisiaj bez specjalnych wyrzutów sumienia nowego „boga”, Mamonę (a przecież przed „innymi bogami” ostrzega jedno z przykazań Dekalogu). I chociaż można by wnioskować, że jest to stałe zjawisko w cywilizacji ludzkiej, to jednak jego obecny wymiar przekracza wszystko, co zarejestrowały nasze dzieje.

W dramatopisarstwie słoweńskim temat rozpadu wartości chrześcijańskich podejmują aż trzy teksty dramatyczne: dwa autorstwa Jančara i jeden Möderndorfera. Pierwszy to omówiona już wcześniej sztuka Lekka jazda Jančara. Podstawą głównego konfliktu jest symboliczne rozszczepienie świata na dwa: na zglobalizowany świat miejski i idylliczny, ocalający chrześcijańskie wartości świat wiejski, co automatycznie zakłada również eschatologiczną sprawiedliwość. Dla odbiorcy słoweńskiego symbolika ta ma szczególne znaczenie, albowiem słoweńską prowincję od czasów 
kontrreformacji - zarówno w planie fizycznym, jak i symbolicznym - naznaczyła obecność Kościoła katolickiego i to do tego stopnia, że utożsamiany jest z istotą słoweńskości. Także dla Jančara wnętrze kościoła jest swoistym schronieniem przed zewnętrznym "grzesznym” światem. W symbolu kościoła spotykają się więc dwa idealne porządki: subiektywny i kolektywny. Subiektywnie kościół jest oazą spokoju, przestrzenią wyciszenia, kontemplacji i bezpieczeństwa, w ujęciu zbiorowości zaś to wyobrażenie wiecznej i niezmiennej sprawiedliwości.

W związku z tym, że chrześcijaństwo tradycyjnie utożsamiano z istotą słoweńskości, kościół wyznaczył jeszcze jeden jej wymiar — swojskość. Przeciwieństwem miasta z jego kosmopolityzmem jest świat gwarantujący stałość wartości i ich ochronę. Dlatego konwersja Maksa dokonuje się poprzez powrót do świata, z którego wyszedł, a więc do świata ruralnego, do jego wartości etycznych i chrześcijańskich. Koronnym dowodem metafizycznego fundamentu całego tekstu jest - oprócz aluzji do Boga jako Stwórcy - symboliczna transformacja fresku, na którym zamiast trzech koni symbolizujących Trzech Króli w drodze do Betlejem, pojawiają się cztery konie Jeźdźców Apokalipsy. Trudno o bardziej wyrazisty i znaczący sposób przekazania przesłania autora.

Fakt, że decyzja Jančara o odwołaniu się do wartości chrześcijańskich nie była przypadkowa potwierdza następna jego sztuka Cicho zegar tyka (2008), skomponowana z siedmiu obrazów luźno powiązanych postaciami dramatu. Obrazy te łączy wspólna tematyka, a mianowicie siedem grzechów głównych. Pierwszy z nich pod tytułem Niewidoczny pył poświęcony jest chciwości (avaritia). Rozmowy o pieniądzach i „finansowej inżynierii” toczone podczas przyjęcia u nowobogackiego prostaka obnażają przywary i ułomności zebranego towarzystwa karierowiczów. Drugi obraz Apteka Nocna, przedstawia nieczystość (luxuria). Jego bohaterka to kobieta, która zmuszona jest opowiadać swojemu partnerowi szczegóły wieczoru, podczas którego dopuściła się zdrady. Trzeci obraz, Siódemka, ukazuje lenistwo (acedia). Podstarzała aktorka staje się ofiarą przemocy kalekiego mężczyzny. Stypa to czwarty obraz na temat obżarstwa (gula). Żałobnicy wspominają przy stole zmarłego, ale wkrótce staje się jasne, że nie mają nic dobrego do powiedzenia, ani o zmarłym, ani o kimkolwiek innym, a zebrali się tylko po to, by się najeść do syta. Piąty obraz ilustruje zazdrość (invidia). Bohatera „oświeca” sam Lucyfer, ten, który przynosi „światło". Gość to przedostatni obraz na temat gniewu (ira). Nad ranem starszą parę budzi gość z zaświatów. Jego śmierci przed laty winien jest mężczyzna, który wymazał to zdarzenie z pamięci. Niewątpliwie chodzi tu o częsty motyw w twórczości Jančara, a mianowicie bratobójcze egzekucje dokonywane przez partyzantów na kolaboracjonistach słoweńskich tuż po II wojnie światowej. Ostatni, siódmy obraz Wahadło podejmuje temat pychy (superbia). Konflikt pomiędzy przedstawicielką ministerstwa kultury a zbuntowanymi artystami kończy scena, w której ciało urzędniczki zawisa w przestrzeni niczym wahadło.

Charakterystyczną cechą sztuki Jančara jest budowanie sytuacji konfliktu między bohaterami, przy czym nie wiadomo, który z nich przekracza granicę, popeł- 
niając grzech. Można go przypisać każdemu z bohaterów, co stawia problem jednoznacznej chrześcijańskiej egzegezy pod dużym znakiem zapytania. Stąd logiczna wątpliwość: Czy w ogóle można twierdzić, że we współczesnym świecie istnieją jasno ustalone kryteria oceny etycznej, czy też należałoby raczej mówić o próbach etycznego połowu w mętnej wodzie? Wydaje się, że Jančar — inaczej niż w sztuce Lekka jazda, gdzie pozycja protagonisty była jasna - wybrał tu inną, słuszniejszą strategię, sugerując, że wszyscy bez wyjątku współtworzymy dzisiejszą Sodomę.

Wśród sztuk, które wyraźnie podkreślają wartości chrześcijańskie, wymienić należy także najnowszy dramat Vinka Möderndorfera pod tytułem Dziesięć, zaskakująco kompleksowy tekst, który w roku 2012 nominowany był do nagrody Gruma. Möderndorfer sięga tu po drugi - oprócz grzechów głównych — temat eschatologicznej egzegezy świata, czyli po Dziesięć Przykazań, posługując się oryginalnym tekstem z piątego rozdziału Deuteronomii (Pięcioksiąg Mojżesza). Przykazania w tej wersji nabierają większej wagi, zakazy są tu bowiem uzasadniane, a towarzyszą im też opisy kar za łamanie nakazów Dekalogu. Möderndorfer komponuje tekst, nie respektując kolejności przykazań, a niektóre $\mathrm{z}$ nich powracają nawet $\mathrm{w}$ różnych wariantach po kilkakroć (przykazanie „nie kradnij” powtarza się dwukrotnie, „nie zabijaj” trzykrotnie), co zapewne ilustruje większą frekwencję ich przekraczania. W ten sposób wytwarza się specyficzne taksonomiczne napięcie, skutecznie broniąc sztukę przed monotonią.

Dramatis personae stanowią trzy pary uosabiające trzy okresy naszego życia: młodość, dojrzałość i starość. Na kanwie Dekalogu splata się tu między bohaterami sieć najrozmaitszych, skomplikowanych relacji. W ten sposób otrzymujemy cały wachlarz sytuacji ilustrujących dynamikę współczesnego społeczeństwa. Sceny łączy w całość opowieść główna, która pojawia się niczym stygmatyzujący leitmotiv, zwracając naszą uwagę na zamianę postaci dramatu. Jest ona zarysowana wokół konfliktów pokoleniowych i powracającego pytania o to, kto ponosi winę (za kłopoty innych).

Przykazania Dekalogu brzmią w sztuce Möderndorfera następująco: Nie będziesz kradzieży czynił. Nie będziesz cudzołożył. Nie będziesz pożądał domu bliźniego twego, ani nie będziesz pragnął żony jego, nie sługi, nie służebnice, nie wołu, nie osła ani żadnej rzeczy, która jego jest. Czcij ojca twego i matkę twoję, abyś był długowieczny na ziemi, którą Pan Bóg twój da tobie. Ja jestem Pan Bóg twój, mocny, zapalczywy, nawiedzający nieprawość ojców nad synami do trzeciego i czwartego pokolenia tych, którzy mię nienawidzą. I czyniący miłosierdzie na tysiące tym, którzy mnie miłują i strzegą przykazania mego. Nie będziesz zabijał. Nie będziesz miał bogów cudzych przede mną. Pamiętaj, abyś dzień Sobotni święcił. Dekalog jako temat literacki sam w sobie nie jest, rzecz jasna, pomysłem nowatorskim ani rewolucyjnym, jednak Möderndorfer w swojej sztuce prowokacyjnie odwraca przykazania Dekalogu, kwestionując ich wymowę. A ponieważ mają one oczywiście swoją formę paradygmatyczną, tym samym nasza intuicyjna interpretacja sytuacji i wartości ulega tu przesunięciu.

Czwarte przykazanie, jak wiadomo, zaleca poszanowanie ojca i matki. Zakładamy zatem, że piętnuje niewłaściwą postawę dziecka wobec rodziców. Tymczasem 
u Möderndorfera chodzi o stosunek matki do dziecka, czy szerzej rzecz ujmując, o rodziców emocjonalnie szantażujących, a w konsekwencji molestujących swoje dzieci. W dramacie Dziesięć autor dokonuje etycznej wolty, naruszając ustaloną hierarchię wartości. W subiektywny sposób odwraca je, „nicuje”, zamienia w ich własne przeciwieństwo. W naszym świecie dawne wartości straciły swój blask, rozpadły się i rozproszyły, co sprawia, że dziś należałoby właściwie chronić tych, do których przykazania były adresowane. Renesansowa scala naturae, czyli wielki łańcuch życia, który miał być stworzony przez boską moc, rozpadł się ostatecznie i wynaturzył. Płynna nowoczesność spowodowała „rozmiękczenie” odwiecznych reguł, wypaczyła ich sens, ostatecznie wykolejając świat.

Möderndorfer kończy swoją sztukę obrazem zatytułowanym „i tak świat stał się pustynią”. Bohaterka tej opowieści, stanowiącej ramę kompozycyjną całości, to Dziewczyna, która jako symboliczna pramatka świadomie odlicza ostatnie chwile „starego" świata. „Jestem sama. Ewa bez Adama. Na całym świecie. W całym kosmosie"21. Ponieważ tylko ona przeżyła, jest metaforą nas wszystkich: w pogoni za osobistymi dobrami doczesnymi wyrzekliśmy się wspólnoty, demontując w końcu społeczeństwo. Utraciliśmy nawet to, na czym zależało nam pozornie najbardziej: poczucie bezpieczeństwa i satysfakcji. Osiągnęliśmy skutek przeciwny do zamierzonego: zostaliśmy sami, ograbieni ze wszystkiego. Jesteśmy niczym „jętki jednodniówki”. Dziewczyna uświadamia to sobie z całą mocą:

I planeta zderzyła się z inną planetą i nadszedł koniec. W snach. Na filmie. W jednej chwili koniec wszystkiego. Dziesięcioro przykazań. [...] Koniec wszystkiego. Nie tylko człowieka. Wszystkich ludzi. A śmierć wszystkich ludzi to prawdziwa nicość. Żadnego dalszego ciągu. Żadnej moralności. Żadnego Boga, który by zapłakał. Nikt w kosmosie nie będzie za nami tęsknił. Kto? Co? Istota? Byt? Nic. Cierpienie? Nic. Nic. I sens? Przekaz? To, co pozostanie. Jeśli zostanie. Nie zostanie. Co ma sens, jeśli na końcu jest ciemność. I będzie ciemność. Wieczna. Gdy policzę do dziesięciu, stanie się ciemność22

\section{IV}

Rozkład współczesnego społeczeństwa, odrzucenie wartości, wyizolowanie dzisiejszego człowieka to stałe motywy współczesnego dramatu słoweńskiego. Dzisiejsze społeczeństwo, podobnie jak i świat, zostały zawłaszczone przez kapitał, który ma za cel (wz)bogacić się bez skrupułów kosztem tych, którzy jeszcze cokolwiek posiadają. Dlatego trzeba było rozbić organiczoność „twardej” nowoczesności, a ludzi wyalienować. Ludzie już organicznie nie przynależą do współczesnego społeczeństwa. Nie stanowią jego części składowej, są po prostu towarzyszami podróży ${ }^{23}$. W społeczeństwo wpisujemy się jako wolontariusze, nie jesteśmy jego częścią organiczną. Wy-

\footnotetext{
${ }^{21}$ V. Möderndorfer, op. cit., s. 783-849.

22 Ibidem.

${ }^{23}$ Bauman opisuje ich jako „członków”, idem, Globalization: the human consequences, s. 41.
} 
daje się nam, że możemy sami decydować o przynależności do tego „klubu”, jednak coraz więcej ludzi już takiego wyboru nie ma: to ludzie „odrzuceni”, agambenowscy „święci”. I coraz więcej jest tych, których karta klubowa straciła ważność.

Współczesny dramat słoweński jasno i wiernie odzwierciedla wkroczenie człowieka w baumanowski świat „płynnej nowoczesności”. W nowoczesności tej „znikają sił[y], które potrafiły utrzymać kwestię porządku i systemu w politycznej agendzie"24. Jednostkom, na które oddziałuje nowa moc, ziemia usuwa się spod nóg, ogarnia je strach, chwytają się nawet brzytwy, wyciąganej ku nim przez panujących. A im mocniej pragną poprawy swojego bytu, tym szybciej w panice idą na dno. Wszyscy wspomniani tu autorzy jasno i wyraźnie rejestrują kres wszelkiej ludzkiej pewności i poczucia bezpieczeństwa.

Jednocześnie staje się jasne, że chodzi o linię, której nie powinno się zakreślać, a co dopiero jej przekraczać. I wcale nie od rzeczy będzie pytanie, czy w ogóle kogoś to jeszcze martwi. Współczesny słoweński dramat można zatem rozumieć jako rozpaczliwe wołanie do współczesnych o ratunek. I choć czasem jego twórcy wątpią, czy ratunek ów jest jeszcze możliwy, to nadal stawiają pytania: Czy potrafimy dostrzec wokół siebie pustkę po utraconych wartościach? Czy naprawdę zmierzamy już ku wesołej apokalipsie? Ile czasu nam jeszcze pozostało?

${ }^{24}$ Z. Baumann, Tekoča moderna, s. 11. 